those estimated to have glands weighing $70 \mathrm{~g}$. or more, who were treated at a dose level of $300 \mu \mathrm{Ci} / \mathrm{g}$. The results obtained with this regimen when analysed according to the size of the goitre showed that the proportion of patients who became hypothyroid was greatest in those with small goitres and became progressively less with increase in size of the goitre. The incidence of residual thyrotoxicosis, on the other hand, showed the reverse trend, being highest in patients with large goitres. These data suggested that a large thyroid gland required a larger radiation dose per gramme of tissue than a smaller gland. An alternative explanation might be that the tendency to underestimate size becomes greater with increase in size of the gland. In practical terms it seemed appropriate to use a dose level of ${ }^{131}$ I which varied according to the size of the gland.

An incidence of hypothyroidism of $5 \%$ at one year is probably acceptable, and it would seem impracticable to attempt to reduce it any further. The natural history of the disease suggests that a certain incidence of hypothyroidism is to be expected with any method of treatment, and the incidence after surgery is probably rather higher than is generally realized. Hedley et al. (1969), for instance, traced 150 patients treated surgically for thyrotoxicosis between 1946 and 1965, and found the total incidence of hypothyroidism to be $38 \%$. Nofal et al. (1966) estimated that $43 \%$ of surgically treated patients would become hypothyroid within 10 years of treatment.

Treatment for the patients who were still hyperthyroid after ${ }^{1: 31}$ I and two courses of treatment with carbimazole has clearly been unsatisfactory. In retrospect some alternative plan would have been preferable, but we cannot yet identify this small proportion of patients, about $10 \%$ of the total number treated, who eventually proved to be unresponsive to the combined method of treatment.

Hagen et al. (1967) compared high- and low-dosage levels in a series of thyrotoxic patients. In the low-dosage group, who were given a dose of $80 \mu \mathrm{Ci}{ }^{131} \mathrm{I}$ per estimated gramme of thyroid tissue, the incidence of hypothyroidism after a mean follow-up period of 19 months was $6 \%$. Our results with regard to the incidence of hypothyroidism are similar to those of Smith and Wilson (1967). They reduced the incidence of hypothyroidism to $4.3 \%$ in a group of patients given a radiation dose of 3,500 rads, though at this dosage level $65 \%$ of the patients were still toxic after one treatment. The cumulative incidence of hypothyroidism in their patients was $7.4 \%$ at five years. We are not able at this stage to estimate the cumulative incidence of hypothyroidism in the patients we have treated with low doses of radioactive iodine.

\section{Conclusions}

The method of treatment described here has effectively reduced the initial incidence of hypothyroidism. A dosage scheme in which the dosage level is related to thyroid size is probably more appropriate than a uniform dose level for all patients.

\section{REFERENCES}

Beling, U., and Einhorn, J. (1961). Acta Radiologica, 56, 275.

Dunn, J. T., and Chapman, E. M. (1964). New England fournal of

Medicine, 271, 1037.
Goolden, A. W. G., and Fraser, T. R. (1969). British Medical fournal, 3,443 .

Green, M., and Wilson, G. M. (1964). British Medical fournal, 1, 1005. Greig, W. R., Crooks, J., and Macgregor, A. G. (1966). Proceedings of the Royal Society of Medicine, 59, 599.

Hagen, G. A., Ouellette, R. P., and Chapman, E. M. (1967). New England Fournal of Medicine, 277, 559.

Hedley, A. J., Tulloch, M. I., Ross, I. P., Michie, W., Beck, J. S., and Crooks, J. (1969). Scottish Medical fournal. In press.

McGirr, E. M., Thompson, J. A., and Murray, I. P. C. (1964). Scottish Medical fournal, 9, 505 .

Nofal, M. M., Beierwaltes, W. H., and Patno, M. E. (1966). fournal of the American Medical Association 197, 605

Smith, R. N., and Wilson, G. M. (1967). British Medical fournal, 1, 129.

\title{
Effect of Pretreatment with Carbimazole in Patients with Thyrotoxicosis Subsequently Treated with Radioactive Iodine
}

\author{
A. W. G. GOOLDEN,* M.B., D.M.R.T. ; T. RUSSELL FRASER, † M.D., F.R.C.P.
}

British Medical fournal, 1969, 3, 443-444

Summary : Preliminary treatment with carbimazole in a $\checkmark$ series of 181 patients with thyrotoxicosis selected for treatment with radioactive iodine did not make any significant difference to the subsequent response to ${ }^{131} I$ therapy.

\section{Introduction}

One disadvantage of ${ }^{131}$ I therapy for thyrotoxicosis, particularly when low doses are used, is that the therapeutic effect is rather slow. In patients with severe thyrotoxicosis it is of ten desirable to control the disease as quickly as possible by means of an antithyroid drug. The remission rate, however, as judged by the proportion of patients who were cured by one dose of ${ }^{131} \mathrm{I}$,

* Consultant Radiotherapist, Hammersmith Hospital, London W.12. + Professor of Clinical Endocrinology, Royal Postgraduate Medical School
of London, London W.12. was lower in patients who had been previously treated with methylthiouracil (Crooks et al., 1960). It was concluded from these findings that pretreatment with methylthiouracil rendered the gland relatively radioresistant. Similar observations have been made in the case of propylthiouracil (Einhorn and Säterborg, 1962). For a number of years we had been using carbimazole to control thyrotoxicosis before ${ }^{131} \mathrm{I}$ therapy and it seemed advisable to find out whether this drug had a similar effect. The effect of pretreatment with carbimazole was accordingly investigated in patients who had been treated with ${ }^{131} I$ for thyrotoxicosis between 1960 and 1963.

\section{Methods}

Patients selected for ${ }^{131} \mathrm{I}$ therapy were divided into two groups according to whether or not they were given preliminary 
treatment with carbimazole, this being decided on a random basis. Patients pretreated with carbimazole were given the drug for a period of two to four months; administration was stopped at least 48 hours before giving a pretherapeutic test dose of ${ }^{131} \mathrm{I}$. The amount of thyroid tissue and the 24-hour uptake were taken into account in determining the activity which was given to the patient, the therapeutic dose (D) being calculated on the basis of $150 \mu \mathrm{Ci}$ of ${ }^{131} \mathrm{I}$ per gramme of thyroid tissue according to the formula :

$$
\mathrm{D}=\frac{\mathrm{M} \times 150}{1,000} \times \frac{100}{\mathrm{U}} \mathrm{mCi}
$$

where $M=$ the mass of the thyroid in grammes and $U=$ the percentage uptake of ${ }^{131}$ I by the thyroid at 24 hours.

All patients were treated at the above dose level $(150 \mu \mathrm{Ci} / \mathrm{g}$.) except for those estimated to have glands of $70 \mathrm{~g}$. or more, who were treated at a dose level of $300 \mu \mathrm{Ci} / \mathrm{g}$. The size of the gland was estimated by palpation. The interval between stopping treatment with carbimazole and giving the therapeutic dose was from three to five days. A final assessment of the response to a single dose of ${ }^{131}$ I was made one year after treatment.

Effect of Pretreatment with Carbimazole on the Subsequent Response to

\begin{tabular}{|c|c|c|c|c|c|c|}
\hline \multirow{2}{*}{\multicolumn{3}{|c|}{ Treatment }} & \multirow{2}{*}{$\begin{array}{l}\text { No. of } \\
\text { Cases }\end{array}$} & \multicolumn{3}{|c|}{ Response to ${ }^{131}$ I Therapy (\%) } \\
\hline & & & & Euthyroid & Hypothyroid & Toxic \\
\hline $\begin{array}{l}\text { Carbimazole } \\
\text { Nil } \quad .\end{array}$ & $\ddot{x}$ & 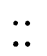 & $\begin{array}{l}83 \\
98\end{array}$ & $\begin{array}{l}63 \\
67\end{array}$ & $\begin{array}{l}14 \\
13\end{array}$ & $\begin{array}{l}23 \\
20\end{array}$ \\
\hline
\end{tabular}

\section{Results}

Pretreatment with carbimazole did not make any significant difference to the subsequent response to ${ }^{131} I$ therapy (see Table). The data suggest that pretreatment with this antithyroid drug does not affect radiosensitivity.

\section{Discussion}

Pretreatment with methylthiouracil and propylthiouracil in thyrotoxicosis modified the response to ${ }^{131} \mathrm{I}$ therapy (Crooks et al., 1960 ; Einhorn and Säterborg, 1962). Thiourea, which contains a sulphydryl radical, and related compounds such as thiouracil have a protective effect on tissues subjected to irradiation (Forssberg, 1950; Mole et al., 1950; Limperos and Mosher, 1950). Other compounds containing a sulphydryl group also have a radioprotective action (Bacq, 1954 ; Gray, 1954). Carbimazole does not contain a sulphydryl group, and our results do not give any indication that pretreatment with this drug modifies the response of thyrotoxic patients to subsequent treatment with ${ }^{131}$ I.

\section{REFERENCES}

Bacq, Z. M. (1954). Acta Radiologica, 41, 47.

Crooks, J., Buchanan, W. W., Wayne, E. J., and MacDonald, E. (1960). British Medical foumal, 1, 151

Einhorn, J., and Säterborg, N. E. (1962). Acta Radiologica, 58, 161.

Forssberg, A. (1950). Acta Radiologica, 33, 296

Gray, L. H. (1954). Acte Radiologica, 41, 63.

Limperos, G., and Mosher, W. A. (1950). Science, 112, 86.

Mole, R. H., Philpot, J. St. L., and Hodges, G. R. V. (1950). Nature, 166, 515 .

\title{
Serological Studies in Infectious Mononucleosis
}

\author{
J. E. BANATVALA,* M.D., м.C.PATH., D.P.H., D.C.H. ; SALLY G. GRYLLS, $†$ M.sc.
}

Sumpras ummary : Serological investigations performed on 27 patients with illnesses resembling infectious mononucleosis showed a significant increase in high antibody titres (more than $1: 40$ ) to EB virus in 11 of the 12 who developed heterophile antibodies. Two of these patients, however, had a significant increase in antibody titre to cytomegalovirus and rubella virus, respectively. Of 15 patient who failed to develop heterophile antibodies, one had a high antibody titre to EB virus, the others generally having undetectable or low antibody titres. The insidious onset of the illness in many patients together with the fact that $\mathrm{EB}$ virus antibodies rose to high titres rapidly reduced the value of this investigation diagnostically.

EB virus antibody was still present in the sera of five patients who bad had well-authenticated heterophileantibody-positive infectious mononucleosis some four to seven years previously. Twenty-seven out of 70 (39\%) healthy nurses had antibody at a level of more than $1: 10$ to EB virus. The presence of EB virus antibody in different population groups appears to be related to such factors as age and socioeconomic status.

\section{Introduction}

Infectious mononucleosis is one of the last common infectious diseases presumed to be of viral aetiology in which a causative agent has still to be clearly established. Attempts to isolate viruses in cell culture have generally been unrewarding, though evidence of infection by cytomegalovirus has been obtained in some patients with illnesses resembling infectious mononucleosis but with no heterophile antibodies (Klemola and Kääriäinen, 1965 ; Klemola et al., 1967). More recent studies conducted by Henle et al. (1968) in Philadelphia and by Niederman et al. (1968) and Evans et al. (1968) at Yale have shown that patients with infectious mononucleosis who develop heterophile antibodies also have significant rises in or already have high antibody titres to EB virus, a herpes-like virus which has been detected in several cell lines from cases of Burkitt's lymphoma (Epstein et al., 1964, 1965 ; Stewart et al., 1965). Unlike heterophile antibodies, antibodies to EB virus persist for long periods, probably indefinitely, and the presence of these antibodies correlates well with immunity to infectious mononucleosis

* Senior Lecturer.

† Leukaemia Fund Research Assistant.

Clinical Virology Department, St. Thomas's Hospital, London S.E.1. 